\title{
ACADEMIC FREEDOM AND LOYALTY OATHS
}

\author{
Arval A. Morris*
}

"Loyalty must arise spontaneously from the hearts of people who love their country and respect their government."

-Mr. Justice Black, concurring in Speiser v. Randall, 357 U.S. 5I3, $53^{2}$ (1958).

\section{INTRODUCTION}

What is academic freedom? It is not an unalloyed concept, and its meanings have many hues and variations. Yet, put simply, but in a somewhat restrictive way, academic freedom at least means that the men of learning within an institution devoted to scholarship must be free to engage in their pursuits. ${ }^{1}$ In this sense, academic freedom applies to all scholars whether they be members of a faculty or student body. ${ }^{2}$ Its specific referent is to that common calling of the intellectual life, the pursuit and understanding of truth, which serves as the adhesive for an otherwise amorphous group known as the community of scholars. In a more complex sense, academic freedom also refers to a place of meeting and to a condition of society. In years past, scholars performed their functions by gathering together in the academy, ${ }^{3}$ the first of which was founded by Plato. In today's interdependent world, the "academy" consists of our colleges and universities whose true functions, in a free society, are threefold: the creation, communication, and conservation of knowledge. ${ }^{4}$ It is on our campuses where one finds an immediate need for academic

- B.A. I951, Colorado College; M.A. 1952, LL.B. I955, University of Colorado; LL.M. I958, Yale University. Professor of Law, University of Washington. Member of the Colorado bar and the American Bar Association.

${ }^{1}$ See R. M. Maciver, Academic Freedom IN OUR TIMe (I955). This book develops an analysis of current American problems in academic freedom. For a thorough historical study limited to American colleges and universities, see Richard Hofstadter \& Walter Metzger, The Development of Academic FREedoM IN THE UNITED STATES (1955). For a history of freedom of teaching in schools below college grade, see the works by Howard K. Beale, A History of Freedom of Teaching in American Schools (I94I), and ARE AMerican TeAChers Free? (1936). For additional materials and their insightful development see the excellent chapter on "Academic Freedom" in Thomas I. Emerson \& Davib Haber, Political and Civil Rights in the United States (1958). Also note, Machlup, On Some Misconceptions Concerning Academic Freedom, 41 A.A.U.P. BuLI. 753 (I955); Carr, Academic Freedom, the American Association of University Professors, and the United States Stspreme Court, 45 id. 5 (1959), and see Ingraham, Academic Freedom, ior Proceedings of the American Philosophical Soc'y 44I (1957).

${ }^{2}$ For discussions of the student interest in academic freedom, see MAcIver, op. cit. supra note $I$, at 205-23 (1955); Frances E. Falvey, Student Participation in College Administration (i952); and Metzger, The German Contribution to the American Theory of Academic Freedom, 4I A.A.U.P. BuLL. $21_{4}$ (1955). For a discussion of loyalty qualifications for students, scholarships and textbooks, see, Willcox, Invasions of the First Amendment Through Conditioned Public Spending, 4I CoRnerL L.Q. I2 (1955), and see, Note, 28 IND. L.J. 520 (1953).

Academic freedom appears tied to its institutional fabric and is a modern term for an old, but still excellent, idea. Its modern version seems to have emerged concurrently with the rise of the university during the medieval period. For more discussion, see Hastincs Rasholal, The Universities of Europe in the Middle Ages (3 vols., i895) (F. M. Powicke \& A. B. Emden, ed. 1936); Percy S. Allen, The age of Erasmus (igr4), and Irene Parker, Dissenting Academies in England (rgr4).

'See Greene, The Function of the School in a Modern Democratic Society, found in Thoms I. 
freedom and where one locates its practitioners. Yet, viewed in its implications beyond our campuses, academic freedom has a social meaning. There appears to be a direct and functional tie between faculty members' claims for academic freedom, the true nature of our colleges and universities, and a continued flow of information into our market place of ideas which is so vital for a free and democratic society. The direct dependence of such a society upon free universities, ${ }^{5}$ and hence, upon academic freedom, is obvious; and these pages need not be cluttered with its prolonged argument accompanied by documentation. ${ }^{6}$

When a claim of academic freedom is made, it carries several necessary implications for conditions of employment, and the demands spring from the nature of the claim itself. Within the confines of a university, knowledge is its own end, not merely a means to an end. The essence of the institution is epitomized by the spirit of free inquiry: to follow the argument wherever it may lead; to examine, question, dispute, or rework customary ideas and beliefs. To a scholar unchallengeable dogma and hypothesis are fundamentally incompatible, and the concept of an immutable doctrine is repugnant to the very life spirit of a university. "The concern of its true scholars is not merely to add and revise facts in relation to an accepted framework, but to be ever examining and modifying the framework itself." tion of academic freedom for the conditions of employment is, therefore, that, if it is to carry out its calling, official governmental intervention must be excluded from

Emerson \& David Haber, Political and Civil Rights in the United States 972 (i958); Reginald S. K. Seeley, Function of the University (1948); John Henry (Cardinal), Newman, The Idea of A UnIversity (1842), and Tauber, The Free University in an Open Society, 23 HAnv. Educ. Rev. 3 (1953).

"University" and "college" are used synonymously with "higher education" throughout this article.

- For one who insists, however, he might consult the following: West Virginia v. Barnette, 319 U.S. 624 (1943), and American Historical. Ass'N, Report of the Commission on Social Studies, Conclusions and Recommendattons (I934); John Dewey, Democracy and Education (19i6) and Problems of Men (i946); Herman H. Horne, The Democratic Philosophy of Education (1935); Alexander Meiklejohn, Eddcation between two Worlds (I942); National Educational Ass'N, The Unique Function of Education in American Democracy (1937); John S. Brubacher, Modern Philosophies of Education (I950) and John S. Brubacher (Ed.), Eczectic Philosophy of Educatjon (I95I); and specifically for lawyer education, see Lasswell \& McDougal, Legal Education and Public Policy: Professional Training in the Public Interest, 52 YALE L.J. 203 (1943), rcprinted in MYres S. McDougal, Studies in World Public Order (1960). The general viewpoint of the above selections might be contrasted with that reported in George F. KNeller, The Educational Philosophy of National Socialism (1941); Boris P. Yesipov \& N. K. Goncharov, I Want to Be Like Stalin (I947), and Munger, Academic Freedom under Peron, 7 ANmoch Rev. 275 (1947).

"I do not use the terms "knowledge" and "truth" to mean the same things. Sec MacIver, op. cit. supra note $\mathrm{I}$, at 3-7. Broadly speaking, "truth" can be considered as those relationships and/or facts which men discover, by their own operations, and its test is whether or not an asserted proposition is in accord with the facts; that is, a statement is true when researchers agree that the fact or conncetion it asserts has been found to exist. Knowledge, on the other hand, is neither the data, the figures, the graphs, nor the instrument readings. Knowledge inheres in those conclusions which are rationally inferred from the data. It can be considered as the entire body of relationships known to be true plus their necessary conclusions and implications. In this sense then, truth and knowledge are mutually interdependent, and for the genuine scholar the quest for knowledge is also a search for truth; they are goals sought for their own sake, and never completely obtained. As H. T. Pledge states in his book, ScIEnce Since 1500, at 54 (1947): "It is philosophies rather than scientific discoveries which are persecuted." In short, knowledge.

${ }^{8}$ Sweezy v. New Hampshire, 354 U.S. 234, 263 (1956) (concurring opinion). 
the intellectual life of a university. ${ }^{\ominus}$ Intellectual autonomy is crucial. ${ }^{10}$ It matters little whether the governmental intervention is direct and open, or covert and clandestine, for, whatever its forms, if government tends to check the passion and fearlessness of scholars, it will destroy fragile and indispensable qualities necessary for fruifful intellectual labor. One thing is clear, the freedom to reason and dispute on the basis of observation and experiment are the necessary conditions for the generation of that ordered thought which we label "science." This same sense of freedom is necessary to do creative work in the humanities and arts, the pursuit of which, along with science, constitutes the university.

The continued development and protection of this "sense of freedom" is the prime, and ultimately the only, responsibility of those official caretakers of the university: its administration and its legislative body. It is their immediate task to create certain conditions of scholarly employment, at least four, which are critical to a realization of "the sense of freedom." Upon these academic caretakers is placed the continuing responsibility of maintaining these conditions inviolate. These conditions have been cast into words by a former Supreme Court Justice who has known well their relation to academic freedom and who has enjoyed an illustrious career at Harvard, Mr. Justice Frankfurter: ${ }^{11}$

It is the business of a university to provide that atmosphere which is most conducive to speculation, experiment and creation. It is an atmosphere in which there prevail "the four essential freedoms" of a university-to determine for itself on academic grounds who may teach, what may be taught, how it shall be taught, and who may be admitted to study.

Besides having obvious implications for governing boards, presidents, and state legislatures, the four essential conditions of academic freedom also have some necessary implications for our society as a whole and for constitutional law. They work out their manifestations in various ways, but are bound up, in their most immediate sense, in a professorial claim for academic freedom. A researcher generally seeks that freedom necessary to investigate an area, to locate data, to interpret his searches into the general fabric of the knowledge available to him at the time, and communicate his considered conclusions to anyone willing to listen. Viewed in this narrow perspective, the professor's immediate claim is for personal protection; that is, the protection necessary to carry out his professorial functions without governmental interference, and without fears of subsequent harassment or penalties being visited upon him for his labors. This is no small claim when one considers its implications for vested social interests, particularly when the claim is examined in relation to the

o "Academic freedom is the freedom of the teacher or research worker in higher institutions of learning to investigate and discuss the problems of his science... without interference from political or ecclesiastical authority or from the administrative officials of the institution in which he is employed, unless his methods are found by qualified bodies of his own profession to be clearly incompetent or contrary to professional ethics." I ENcrc. Soc. ScI. 384 (1930).

${ }^{10}$ See the inaugural address of University of Washington President, in Charles E. Odegaard, MaN and LeARning in MOdern Society 173 (1958).

${ }^{11}$ Sweezy v. New Hampshire, 354 U.S. 234,263 (1956) (concurring opinion). 
conclusions that conceivably might emanate from courageous and challenging investigations into the fabric of our social order. Yet, obviously, such investigations must be made if a democratic society is to function. "Teachers and students must always remain free to inquire, to study and to evaluate, to gain new maturity and understanding; otherwise our civilization will stagnate and die."12 Thus, in a broader perspective, it can be seen that a professor's claim for academic freedom really translates itself into a demand for protection, not only for himself, but into a claim of protection for society's right to know. It is an instrument of democracy. In this sense then, academic freedom, with its concomitant intellectual liberty for the scholar and community alike, constitutes the very core of that freedom of speech and association so basic to a free society and so carefully safeguarded by the first amendment to our Constitution.

\section{I}

\section{Constituttonal Recognition of Academic Freedom}

The clearest recognition by the United States Supreme Court that academic freedom lies at the core of the free speech guarantee of the first amendment, came with its decision in Sweezy v. New Hampshire. ${ }^{13}$ In 1951, that state enacted its Sub. versive Activities $\mathrm{Act}^{14}$ which imposed criminal and civil penalties upon "subversive persons."15 Later, in 1953, the New Hampshire legislature, by resolution, empowered the state attorney general to act as a one-man investigating committee whenever he had information which ". . . in his judgment may be reasonable or reliable." He was directed to investigate violations of the $195 \mathrm{I}$ Act and to report to the legislature on the needs for additional legislation. ${ }^{16}$ Using this authority, the attorney general sought to question Paul Sweezy, an editor, ${ }^{17}$ writer, ${ }^{18}$ and self-proclaimed "socialist" and "classical Marxist." Sweezy testified freely and generally, but he refused to answer any of two types of questions. Relying upon the first and fourteenth amendments, he refused to answer questions concerning the New Hampshire

${ }^{12} I d$. at 250 .

${ }^{13} 354$ U.S. 234 (1956); for discussion see, 7 Buffalo L. REv. 267 (1958); 71 Harv. L. Rzv. X4X (1957); 56 Mich. L. REv. 29I (I957), and 32 N.Y.U. L. REv. 1302 (1957).

14 N.H. Rev. Stat. ANN $\$ \$ 588$ : I-16 (1955).

${ }^{15}$ The first section provides that: "Subversive person means any person who commits, attempts to commit, or aids in the commission, or advocates, abets, advises or teaches, by any means any person to commit, attempt to commit, or aid in the commission of any act intended to overthrow, destroy or alter, or to assist in the overthrow, destruction or alteration of, the constitutional form of government of the United States, or the State of New Hampshire, or any political subdivision of either of them, by force, or violence; or who is a member of a subversive organization or foreign subversive organization." The latter two organizations are defined in terms almost identical to those above. The criminal penalty for violating this act can be a fine of "not more than twenty thousand dollars, or imprisonment for not more than twenty years, or both ..." See $\$ 588: 2$. On the civil side: "No subversive person ... shall be eligible for employment in, or appointment to any office of ... this state . . . or other political subdivision of this state." See $\$$ 588:9.

${ }^{10}$ N.H. Laws, 1953, ch. 307. Note discussion in Nelson v. Wyman, 99 N.H. 33, I05 A.2d 756 (1954).

${ }^{17}$ See, e.g., The Monthly Review.

${ }^{18}$ See, e.g., Paul M. Sweezy, Soctalisa (1949), and Paur M. Sweezy, The Theory op Capitalietic DeVELOPMENT (1942). 
activities of the Progressive Party during the election campaign of 1948 , and he resisted all questions regarding a lecture that he delivered during I954, at the invitation of the faculty for humanities, on the University of New Hampshire campus. Regarding the second category, he refused to answer these specific questions: $:^{19}$

I. "What was the subject of your lecture?"

2. "Didn't you tell the class at the University of New Hampshire on Monday, March 22, I954, that socialism was inevitable in this country?"

3. "Did you advocate Marxism at that time?"

4. "Did you express the opinion, or did you make the statement at that time that socialism was inevitable in America?"

5. "Did you in this last lecture on March 22 or in any of the former lectures espouse the theory of dialectical materialism?"

The lower court found Sweezy in contempt for his failures to answer, and this judgment was affirmed by the state supreme court. ${ }^{20}$

On appeal, the United States Supreme Court reversed, two Justices concurring in a special opinion and two Justices dissenting. Consequently, there was no single opinion for a majority of the Court.

Mr. Chief Justice Warren, joined by Justices Black, Douglas and Brennan, wrote 2n opinion which commented upon the vagueness of the New Hampshire law and which noted the ease whereby legislative investigations conducted under this statute could trespass upon first amendment rights. These four Justices concluded that Sweezy's academic freedom "to lecture and his right to associate with others were constitutionally protected freedoms which had been abridged through this investigation." 21 The opinion continued: ${ }^{22}$

These are rights which are safeguarded by the Bill of Rights and the Fourteenth Amendment. We believe that there unquestionably was an invasion of petitioner's liberties in the areas of academic freedom and political expression-areas in which government should be extremely reticent to tread.

Although this invasion of constitutionally protected freedoms existed, and although these four justices could not "conceive of any circumstance wherein a state interest would justify [an] infringement of rights in these fields, ${ }^{, 23}$ they did not believe that they had to "reach such fundamental questions of state power to decide this case."24 For them, there was a missing link; hence, they put their decision on different grounds. Neither the "expansive definitions" of the statutes, ${ }^{25}$ nor the facts found in the record, revealed "what reasonable or reliable information led the Attorney

\footnotetext{
${ }^{10}$ See Sweezy v. New Hampshire, 354 U.S. 234, 243-44 (1956).

${ }^{20}$ Wyman v. Sweezy, roo N.H. 103, I2I A.2d 783 (1956).

${ }^{21}$ Sweezy v. New Hampshire, 354 U.S. 234, 249-50 (I956).

22Id. at 250 .

${ }^{28}$ Id. at $25 \mathrm{I}$.

at Ibid.

${ }^{25}$ Sec note 15 supra.
} 
General to question the petitioner."26 Thus, the needed nexus was missing which, if present, would have connected the attorney general's questioning of Sweezy with the fundamental interest of the state to protect itself from overthrow by force and violence. In short, these justices could not determine whether the New Hampshire legislature really wanted the information sought from Sweezy. Consequently, "the use of the contempt power, notwithstanding the interference with constitutional rights, was not in accordance with the due process requirements of the Fourteenth Amendment."27

In a concurring opinion, Mr. Justice Frankfurter, joined by Justice Harlan, criticized the Chief Justice for his view that the conviction was invalid due to a missing link. For them, there was no missing link; "the case must be judged as though the whole body of the legislature had demanded the information."28 Therefore, they had to reach fundamental questions of state power under the first and fourteenth amendments.

In deciding the issue, Justice Frankfurter balanced contending principles. Sweezy had put forth the rights of a guest lecturer to academic freedom, as well as the right of a citizen to political privacy. For New Hampshire there was the right of the state to protect itself from overthrow by force and violence. Justice Frankfurter concluded that, on balance, Sweezy had to prevail, primarily because there was no basis for the belief that Sweezy's past activities reasonably constituted a subversive threat, justifying the questioning. "When weighed against the grave harm resulting from governmental intrusion into the intellectual life of a university, such justification for compelling a witness to discuss the contents of his lecture appears grossly inadequate."29 Thus, the claim of academic freedom was given protection and held to come within the ambit of the first and fourteenth amendments. ${ }^{30}$

In a dissenting opinion, Mr. Justice Clark, joined by Justice Burton, struck a balance contrary to that found by Justices Frankfurter and Harlan. The dissenting

${ }^{26}$ Sweezy v. New Hampshire, 354 U.S. 234, 252 (1956).

${ }^{27}$ Id. at 254-55.

${ }^{28}$ Id. at 256. For further criticism, see, Crampton, The Supreme Court and State Posver to Deal with Subversion and Loyalty, 43 MinN. L. REv. 1026, 1048 (1959).

${ }^{20}$ Id. at $26 \mathrm{r}$. "If ... Sweezy decided anything, [it] decided that before inroads in the First Amendment domain may be made, some demonstrable connection with communism must first be established and the matter be plainly shown to be within the scope of the Committee's authority." Douglas, J., in Braden v. United States, 365 U.S. 43r, 456-57 (r 960 ) (dissent).

${ }^{20}$ The reasoning follows: "Progress in the natural sciences is not remotely confined to findings made in the laboratory. Insights into the mysteries of nature are born of hypothesis and speculation. The more so is this true in the pursuit of understanding in the groping endeavors of what are called the social sciences, the concern of which is man and society. The problems that are the respective preoccupations of anthropology, economics, law, psychology, sociology and related areas of scholarship are merely departmentalized dealing, by way of manageable division of analysis, with interpenetrating aspects of holistic perplexities. For society's good-if understanding be an essential need of society-inquiries into these problems, speculations about them, stimulation in others of reflection upon them, must be left as unfettered as possible. Political power must abstain from intrusion into this activity of freedom, pursued in the interest of wise government and the people's well-being, except for reasons that are exigent and obviously compelling." $1 d$. at $26 \mathrm{r}-62$. 
Justices held that New Hampshire's interest in self-preservation justified the intrusion into Sweezy's civil liberties. ${ }^{31}$

The plurality and concurring opinions in the Sweezy case clearly recognize that academic freedom will be given protection under the first and fourteenth amendments; however, it must be academic freedom that is claimed. Nothing in the Sweezy case says that all investigatory power is denied solely because the field of education is involved. ${ }^{32}$ The Court will examine carefully the claim of academic freedom to be sure that it is well taken.

It would appear that subsequent events have confirmed this view; for example, consider Barenblatt $v$. United States. ${ }^{33}$ Its situation was this: Lloyd Barenblatt, a teacher of psychology at Vassar College, was summoned to appear before a Subcommittee of the House Committee on Un-American Activities. But before he actually appeared his contract had expired, and it was not renewed. "He, therefore, came to the Committee as a private citizen without a job."34 Barenblatt was convicted for refusing to answer whether he was then, or ever had been, a member of the Communist Party, or whether he had been "a member of the Haldane Club of the Communist Party while at the University of Michigan."35 It should be noted that these questions do not strike directly at academic freedom in the same manner as those put to Paul Sweezy. On appeal, the Court viewed "the ultimate issue in this case to be whether petitioner could properly be convicted of contempt for refusing to answer questions relating to his participation in or knowledge of alleged Communist Party activities at educational institutions in this country."36 It is clear that this issue is not one of due process, but one involving the first amendment, and hence, similar to the issue considered under Mr. Justice Frankfurter's approach in Sweezy.

The Court affirmed Barenblatt's conviction despite his reliance on Sweezy and other first amendment cases. For the majority, this reliance was misplaced. In his opinion for the Court, Mr. Justice Harlan carefully distinguished the Barenblatt case from the Sweezy case, ${ }^{37}$ referring, inter alia, to note 20 . This note shows

${ }^{31}$ Id. at 270.

${ }^{32}$ See Wilkinson v. United States, 365 U.S. 399,409 (I960).

${ }^{33} 360$ U.S. 109 (1959). I do not deal with Uphaus v. Wyman, 360 U.S. 72 (1959), even though it has important overtones for Sweezy. The reasons are that $U$ phaus did not involve any claim of academic freedom, turning, as it did, solely upon Uphaus' interest in associational privacy and that the Court held Sweezy not to be in point. But compare, Gibson v. Florida, 372 U.S. 539 (1963).

34 Barenblatt v. United States, 360 U.S. 109, I34 (I959) (dissenting opinion).

${ }^{35} I d$. at II4.

${ }^{30} \mathrm{Id}$. at $\times 15$.

${ }^{37} I d$. at 129. "The vice existing there was that the questioning of Sweezy, who had not been shown ever to have been connected with the Communist Party, as to the contents of a lecture he had given at the University of New Hampshire, and as to his connections with the Progressive Party, then on the ballot as a normal political party in some 26 States, was too far removed from the premises on which the constitutionality of the State's investigation had to depend to withstand attack under the Fourteenth Amendment. See the concurring opinion in Sweezy, stupra, at 26r, 265, $266 \mathrm{n} .3$. This is a very different thing from inquiring into the extent to which the Communist Party has succeeded in infiltrating into our universities, or elsewhere, persons and groups committed to furthering the objective of overthrow. Sec Note 20, supra." 
that the investigation in Barenblatt was carefully limited in its scope to communism, and did not aim at academic freedom. It appears that Representative Jackson, a member of the Un-American Activities Committee, had informed the House of Representatives about this particular investigation saying: ${ }^{38}$

I want to point out this is not a blunderbuss approach to the problem of communism in education. We are not interested in textbooks. We are not interested in the classroom operations of the universities. We are interested instead in finding out who the communists are and what they are doing to further the communist conspiracy.

Given the fact that Barenblatt was not questioned about any of his academic activities when he functioned as a professor, ${ }^{30}$ and the fact that the investigation was not aimed at academic freedom, the Court felt that Barenblatt's case differed substantially from Sweezy's. This view necessarily implies that the majority of the Court in Barenblatt construed, and approved, the holding of the Sweezy case in light of its concurring, and not plurality, opinion. That view now commands a majority. Otherwise, the Sweezy case, as holding, would not have been relevant to the issue in Barenblatt. ${ }^{40}$ Consequently, it can be said that, today, Sweezy stands unshaken in this respect: academic freedom has been recognized as properly receiving constitutional protection under the first and fourteenth amendments.

One final case, decided after Sweezy and Barenblatt, fully corroborates this view: Shelton $v$. Tucker. ${ }^{41}$ It does not set matters at rest, but it does have significant implications for several of the four essentials of academic freedom-the right to determine on academic grounds who may teach and under what conditions. An Arkansas statute aimed at the National Association for the Advancement of Colored People (NAACP) but struck academic freedom. It required that every teacher, as a condition of employment, execute an affidavit disclosing every organization with which he had been associated over a five-year period. ${ }^{42}$ Shelton had been a public school teacher for twenty-five years, and he refused to comply. He was notified that his teaching contract would not be renewed, and Arkansas provided nothing comparable to a system of tenure to fall back upon. Thereupon, he brought a class action to enjoin the Arkansas statute on the ground that it deprived "teachers in Arkansas of their rights to personal, associational, and academic liberty, protected by the Due Process clause of the fourteenth amendment from invasion by state action."43 The Supreme Court upheld Shelton's claim. First of all, the Court

${ }^{38} I d$. at I22 n.20.

${ }^{30}$ The only question relating to Barenblatt's academic activity dealt with his relationship, as a student, with the Haldane Club of the Communist Party.

${ }^{10}$ Indeed, Sweezy's concurring opinion, adjudicating the issue on the first and fourteenth amendments, is the only one considered by the Court in Barenblatt. See note 37 supra, and also see Shelton v. Tucker, $3^{6} 4$ U.S. 479,487 (1960), and Poe v. Ullman, $3_{67}$ U.S. $497,5{ }^{14}$ (1960) (dissent).

11364 U.S. 479 (1960).

42 Id. at 480 n.2.

${ }^{18}$ Id. at $484-85$. 
admitted that there could be no question of the relevance of the state's inquiry into the fitness and competence of its teachers. Nevertheless, even though this statute's inquiry was relevant, that alone did not make it constitutional. To the contrary, this inquiry was so unlimited and indiscriminate that it constituted a prior restraint on the exercise of constitutionally guaranteed first amendment freedoms, incorporated into the fourteenth. Thus, the Court struck down the Arkansas statute because, as a condition of employment, it went "far beyond what might be justified in the exercise of the State's legitimate inquiry into the fitness and competency of its teachers." ${ }^{\text {"It }}$ is relevant to note that the Court's opinion relied upon Sweezy ${ }^{45}$ in the academic freedom context of Shelton $v$. Tucker and ignored Barenblatt.

Before the Sweezy case was decided, and without formally recognizing the claim of academic freedom, the Supreme Court actually protected it on several occasions. In Meyer v. Nebraska, ${ }^{46}$ the Court held that a state statute prohibiting the teaching of languages, other than English, in grades one through eight unreasonably infringed upon the liberty guaranteed a teacher by the fourteenth amendment. The Court held that the legislature had "attempted materially to interfere with the calling of modern language teachers, with the opportunities of pupils to acquire knowledge, and with the power of parents to control the education of their own." ${ }^{\mathbf{4} 7}$ Even though the Court approached the issues obliquely and inconclusively, this case did give protection to two of the "four essential freedoms" of academic liberty; namely, the rights to determine on academic grounds what may be taught and who may be admitted to study. When Meyer is combined with Shelton and Sweezy, it can be seen that, in one way or another, the Court has provided at least partial constitutional recognition for three of the four essential freedoms of academic liberty. On the other hand, some state courts have failed to follow the lead of the United States Supreme Court and have not, as yet, given the claim of academic freedom its due measure of recognition. ${ }^{48}$

"Id. at 490 .

${ }^{15} I d$. at 487 .

${ }^{10} 262$ U.S. 390 (I923). See Notes, I2 Calif. L. Rev. I36 (x924); 22 Mich. L. Rev. 248 (I924), and 72 U. PA. L. Rev 46 (I923); also see, Bartels v. Iowa, 262 U.S. 404 (I923); Pierce v. Society of Sisters, 268 U.S. 5 Io (1925), and Note, School Boards, Schoolbooks, and the Freedom to Learn, 59 YALE L.J. 928 (I950).

${ }^{47}$ Id. at 401 . Also note Farrington v. Tokushige, 273 U.S. 284 (I927), which holds unconstitutional an act regulating the teaching of foreign languages because its regulations imposed unreasonable requirements upon schools taught in a foreign language. Note also Mo Hock Ke Lok Po v. Stainback, 74 F. Supp. 852 (D. Haw., I947), rev'd on other grounds, 336 U.S. 368 (I949).

${ }^{48}$ See McDowell v. Board of Education, I04 Misc. 564, I72 N.Y. Supp. 590 (19x8) (dismissal of school teacher because of pacifist beliefs during wartime); also see State v. Turner, r9 So.2d 832 (Fla. 1944); Reed v. Orleans Parish School Board, 2 I So.2d 895 (La. App. 1945) (dismissal for failure to participate in war work activities); Horosko v. School Dist., $335 \mathrm{~Pa}$. 369, 6 A.2d 866 (I939) (dismissal for working in a tavern); Board of Education v. Jewett, 21 Cal. App.2d 64, 68 P.2d 404 (2937) (dismissal for classroom praise of Soviet Union and criticism of United States); Joyce v. Board of Education, 325 Ill. App. 543, 60 N.E.2d 43I (1945) (dismissal for writing a later published letter which encouraged a former student in his failure to register for the draft). Also see Worzella v. Board of Regents, 93

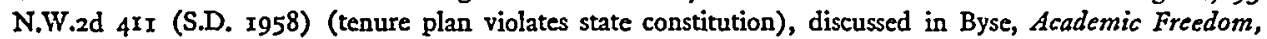
Tenure and the Law, 73 HARv. L. Rev. 304 (1959). 


\section{Loyalty OAths and Security Programs}

Few Americans are fully aware of an amazing network which, with an alarming vitality, has spread throughout American society. ${ }^{49}$ Loyalty-security programs have proliferated to all levels, and programs are currently being administered by federal, ${ }^{\text {to }}$ state, ${ }^{51}$ local ${ }^{52}$ and private agencies. ${ }^{53}$ These programs are all recent newcomers to our social scene. ${ }^{54}$ Loyalty-security measures have multiplied with startling rapidity and can be found almost everywhere..$^{55}$ The most exhaustive study of one aspect of the total problem-loyalty tests as a condition of employment-declares that "the record of the last decade, however, suggests strongly that the hardest thing to do with loyalty programs is to confine them." ${ }^{\text {"56 }}$ The official programs date only from President Truman's 1947 loyalty order for federal employees; and, if legislative investigations are discounted, that event marks the beginning of recent large-scale attempts to measure a man's loyalty as a condition of his employment. ${ }^{.7}$

The total overall impact of loyalty-security programs on our free institutions has yet to be measured, but it must be staggering. It will suffice to consider the implications of one example, confined solely to loyalty as a test of employment. As of $195^{8}$, reliable, and cautious, estimates revealed that a few more than $1,600,000$ professional people (scientists, teachers, lawyers, engineers, and so on) had occupations dependent upon their ability to meet some type of loyalty criteria. Add to these the over $7-1 / 2$ million people in federal, state, and local government, plus the astonishing

${ }^{10}$ Not counting legislative investigations, it appears that loyalty tests have been prescribed as conditions of employment by the federal government for federal civil servants, government contractors and their employees, the Atomic Energy Commission, the Defense Department, certain other military personnel, labor leaders, unclassified researchers, and licensed seamen. States have prescribed loyalty tests for teachers, lawyers, doctors, clergymen, social workers, librarians, veterinarians, state and local civil servants, and so on. See Ralph S. Brown, Loyalty and Security, 2I-119, 164-83 (1958).

${ }^{50}$ See E. Bontecou, The federal Loyalty Security Procram (1953); also see A. Yarmolinsky (Ed.), Case Studies in Personnel Security (1955).

${ }^{51}$ See Walter Gellhorn (Ed.), The States and Subversion (1952); Fund for the Repundic, Digest of the Public Record of Commonism in the United States, Part II, State Statutes and Decisions (1955), and Prendergast, State Legislatures and Communism, 44 AM. PoL. Scr. Rev. 556 (1950).

${ }_{62}$ E.g., see Garner v. Board of Pub. Wks., 34I U.S. 716 (x95I).

${ }^{63}$ See Industrial Relations Research Assoctation, Personnel Security Programs in U.S. Industry (1955); Comment, The Role of Employer Practices in the Federal Industrial Personnel Security Program, 8 Stan. L. REv. 234 (1956), and Comment, Loyalty and Private Employment, 62 YALE L.J. 954 (1953).

54 E.g., employment tests are very little discussed in the standard historical works; but sce Haroud M. Hyman, To Try Men's Souls-loyalty Tests in American History (x959); Harold M. Hymsan, Era of the Oath: Northern Loyaity Tests During the Civil War and Reconstruction (1954), and John C. Mirler, Crusis in Freedom: The Alien and Sedition Acts (1951).

${ }_{5 \sigma}$ E.g., the Indiana Athletic Commission is reported to have a requirement that, before they are allowed to perform, boxers and wrestlers must subseribe to a loyalty oath. RALPH S. BROWN, LOYALTY AND SeCURITY I1 8 (1958), and Walter Gellhorn, in his useful book, Individual FreEdom aNd Governmentas. RESTRAINTS 129-30 (1956) reports that Washington requires a loyalty oath of its veterinarians.

${ }^{86}$ BRown, op. cit. supra note 55, at 338.

${ }^{8 z}$ Exec. Order No. 9835, I2 Fed. Reg. I935 (1947), superseded by Exec. Order No. 10450, 18 Fed. Reg. 2489 (1953). For commentary, see Emerson \& Helfeld, Loyalty Among Government Employees, 58 YALE L.J. 14 (1948). 
figure of over $4-1 / 2$ million people who must meet industrial security tests, and these figures total over $13^{-1 / 2}$ million. Applied to a work force of 65 million, this estimate "means that at least one person out of five, as a condition of his current employment, has taken a test oath, or completed a loyalty statement, or achieved official security clearance or survived some undefined private scrutiny." 58 More importantly, it appears that about II,500 people, the largest single group involved in federal contracts in private employment, for one reason or another, have failed their loyalty tests. Hence, loyality qualifications appear to have barred from employment one person in every $2,500.59$ When applied to teachers and limited to state and municipal governments, it is estimated that approximately $5^{00}$ teachers (school and college) were dismissed between 1948 and I958, mostly for refusals to answer questions or to take loyalty oaths as conditions of employment. ${ }^{60}$ The proliferation of loyaltysecurity measures, and their impact on dissent, leads one seriously to consider whether America is approaching an era of orthodoxy. Perhaps so, but colleges and universities are certainly the last places where such policies should be promoted; however, recent events reveal ominous signs.

It appears that, as of late, the pressures on our universities and colleges have been intensifying, producing new forces for orthodoxy and a spate of attacks on academic freedom. ${ }^{61}$ The American Association of University Professors (AAUP), during I945 to I950, had before it for consideration 227 cases involving academic freedom, not counting many "situations" which are not classified as cases. ${ }^{62}$ During the decade of the fifties, legislative investigations heavily taxed academic freedom, frequently precipitating dismissals from university faculties or non-renewals of term appointments that otherwise would have been granted. ${ }^{63}$ Nineteen cases have been

${ }^{6}$ Brown, op. cit. supra note 55 , at $\mathrm{x} 8 \mathrm{x}$.

${ }^{60}$ Id. at $\mathrm{I} 82$.

${ }^{10}$ Id. at 488 (Appendix A).

${ }^{\circ 1}$ See, e.g., The Lines of Attack on Academic Freedom, Part III, of R. M. Maciver, Academic Freedom in Our Time i23-205 (1955); Am. Civil Liberties Union, Greater Philadelphia Branch, Academic Freedom: Some Recent Philadelphia Episodes (I954), and Note, 42 A.A.U.P. Bull. 75 (1956).

${ }^{03}$ Report of Committee T, 37 A.A.U.P. BuLI. 79 (I95I). For full discussion of the attacks and their aftermath, at the University of Washington, see Ralph S. Brown, LoyalTy AND SECuRITY 120-22 (1958), Vern Countryman, Un-American Activities in the State of Washington (I95I) and Board of Regents, University of Washington, Communism and Academic Freedom (I949). For the California situation, see George R. Stewart, The Year of the Oath (1950); Tolman v. Underhill, 229 P.2d 447 (Cal. App. I95I), and Kantorowitz, The Fundamental Issue, Documents and Marginal Notes on the University of California Loyalty Oath (1950), and gote generally, John W. Caughey, In Clear and Present Danger (1958). These materials do not speak fully to the intimidations which were generated.

os See chapter 2 of Paul F. Lazarsfeld \& Wagner Thielens, The Academic Mind (1958). As the case of Professor Rupert C. Koeninger demonstrates, the technique of failing to recommend reappointment is not confined to the younger faculty members. It appears that, because of certain political activities, and after fourteen years of service to Sam Houston State Teachers College, Professor Koeninger's name, on May 4-6, 1961, was not among those recommended for reappointment to the institution. The political activities charged to Professor Koeninger seem to have consisted of ( $I$ ) delivering a keynote address on "The First Year of Integration" before a meeting of the Southern Conference Educational Fund; (2) helping to set up booths to collect money for the payment of poll taxes; (3) signing a petition, using the title "professor" which endorsed a candidate for judicial office; (4) questioning a congressman, at an open 
reported, and they usually have involved a faculty member who refused to answer a question, thereby stimulating the employing institution to undertake action that ultimately led to his dismissal..$^{84}$ In some of the cases, it is true, the faculty members, as well as the administrations, ${ }^{65}$ were at fault; nevertheless, this fact does not decrease the impact of the investigations on the "spirit of freedom" so essential to an academic community. In addition, there were fourteen dismissals from New York City municipal colleges ${ }^{68}$ under a law which later was found to be unconstitutional. ${ }^{07}$ Furthermore, R. E. Combs, counsel to the California Senate Committee on UnAmerican Activities, has testified that a number of college and university presidents in California have arranged for "clearance" from the state committee of all new appointees to their faculties, and privately to receive "derogatory information" regarding their present staffs. ${ }^{68}$

The loyalty oath, in addition to legislative investigations, is another device which directly attacks free inquiry and expression. It is the predominant loyalty-security device used by state and local governments as a condition of employment.0 Oaths are basically of two types: the positive pledge and the negative disclaimer. Today,

meeting, about his reasons for voting to uphold a presidential veto of a bill; (5) engaging in " $a$ political hassle" with a student, and (6) disputing the veracity of the film "Operation Abolition" three weeks prior to the board meeting at which he was not rehired. For more discussion see 49 A.A.U.P. BuzL. 44 (1963). Among other things, Professors Koeninger's situation illustrates the need for a functioning system of tenure. See Clark Byse \&e Louis Joughin, Tenure in American Higher Education (1959), and Byse, Academic Freedom, Tentre, and the Law, 73 HArv. L. Rev. 304 (1959).

${ }^{6}$ See Brief of Amieus Curiae (AAUP), in Barenblatt v. United States, 360 U.S. 109 (I959) at p. I6 where the following chart appears:

\begin{tabular}{|c|c|c|c|c|c|}
\hline Name of Institution & $\begin{array}{l}\text { Number of } \\
\text { Dismissals }\end{array}$ & $\begin{array}{l}\text { Group Putting } \\
\text { the Question }\end{array}$ & \multicolumn{3}{|c|}{$\begin{array}{l}\text { Reference to } \\
\text { AAUP Bulletin }\end{array}$} \\
\hline Dickinson College & $\mathbf{r}$ & HCUA & 44 & : & 137 \\
\hline New York University & $I$ & $\begin{array}{l}\text { ISC } \\
\text { HCUA }\end{array}$ & 44 & : & 22 \\
\hline Ohio State University & I & HCUA & 42 & : & $8 x$ \\
\hline Reed College & I & HCUA & 44 & : & 102 \\
\hline Rutgers University & 2 & ISC & & & \\
\hline & I & HCUA & 42 & $:$ & 77 \\
\hline Temple University & I & HCUA & 42 & : & 79 \\
\hline University of Kansas City & I & ISC & 43 & : & 277 \\
\hline University of Michigan & 2 & HCUA & 44 & : & 53 \\
\hline University of Southern California & I & HCUA & 44 & : & 151 \\
\hline University of Vermont & I & ISC & 44 & : & II \\
\hline University of Washington & 3 & State Legislature & 42 & : & 61 \\
\hline Wayne University & 2 & HCUA & 42 & : & 87 \\
\hline
\end{tabular}


Goodman, The Community of Scholars (x962).

${ }^{60} \mathrm{Sec} 42$ A.A.U.P. Bulz. 7 I (1956). See, e.g., Daniman v. Board of Education, 306 N.Y. 532, I19 N.E.2d 373 (r954).

${ }^{67}$ Slachower v. Board of Higher Education, 350 U.S. 55I (I955).

${ }^{68}$ Hearings Before the Subcomm. to Investigate the Administration of the Internal Security Act of the Sen. Comm. on the Judiciary, Subversive Influence in the Educational Process, 83d Cong., rst Sess. 605-22 (1953); and see Gerstel, G-Men on the Campus, The Nation, Jan. 30, 1954, p. 93.

${ }^{\circ}$ Ralph S. Brown, Loyalty and Security 92 (1958); Walter Gellhorn (Ed.), The States and Subversion (1952); and E. Edmund Reuter, The School Administrator and Sunversive Activities (195r). 
at least twenty-six states impose a disclaimer-type test oath on all their employees, including teachers. ${ }^{\mathbf{7 0}}$ They demand a negation of certain activities. The disclaimers require that the employee, in sweeping terms, swear that he is not subversive and that he will not be subversive, and, in some cases, that he has never been subversive. ${ }^{71}$

On the other hand, oaths requiring a pledge refer to positive, rather than negative actions. Generally, they have been prescribed exclusively for teachers, as distinguished from all other state employees. The one required by the state of Washington is an example, and it applies to all teachers, including university faculty: ${ }^{72}$

${ }^{70}$ They are Alaska, Arkansas, California, Florida, Georgia, Hawaii, Idaho, Illinois, Kansas, Louisiana, Maryland, Massachusetts, Minnesota, Mississippi, Montana, Nebraska, New Hampshire, New Jersey, Ohio, Oklahoma, Oregon, Pennsylvania, South Dakota, Texas, Washington, and West Virginia. See, Brown, op. cit. supra note 69 , at 92 n.2.

${ }^{71}$ The one for the state of Washington is an example; it requires the following:

"I certify that I have read the provisions of $\$ 9.8 \mathrm{r}$.oro (2), (3), and (5), $99.8 \mathrm{r} .060$, $\$ 9.81 .070$, and $\$ 9.81 .083$ of the Washington Revised Code, which are printed on the reverse hereof, that I understand and am familiar with the contents thereof; that I am not a subversive person as therein defined; and

"I do solemnly swear (or affirm) that I am not a member of the Communist Party or knowingly of any other subversive organization.

"I understand that this statement and oath are made subject to the penalties of perjury."

"Public Employment-Subversive Person Ineligible.-No subversive person, as defined in this act, shall be eligible for employment in, or appointment to any office, or any position of trust or profit in the government, or in the administration of the business, of this state, or of any county, municipality, or other political subdivision of this state." WASH. REv. CODE $\$ 9.81 .060$ (Supp. I956).

"Definitions.-(5) 'Subversive person' means any person who commits, attempts to commit, or aids in the commission, or advocates, abets, advises or teaches by any means any person to commit, attempt to commit, or aid in the commission of any act intended to overthrow, destroy or alter, or to assist in the overthrow, destruction or alteration of, the constitutional form of the government of the United States, or of the state of Washington, or any political subdivision of either of them by revolution, force, or violence; or who with knowledge that the organization is an organization as described in subsections (2) and (3) hereof, becomes or remains a member of a subversive organization or a foreign subversive organization." WASH. REV. CODE $\$ 9.81$.oro(5).

"(2) 'Subversive organization' means any organization which engages in or advocates, abets, advises, or teaches, or a purpose of which is to engage in or advocate, abet, advise, or teach activities intended to overthrow, destroy, or alter, or to assist in the overthrow, destruction or alteration of, the constitutional form of the government of the United States, or of the state of Washington, or of any political subdivision of either of them, by revolution, force or violence." WASH. REv. CODE $\$ 9.8 \mathrm{I} .0 \mathrm{IO}(2)$.

"(3) 'Foreign subversive organization' means any organization directed, dominated or controlled directly or indirectly by a foreign government which engages in or advocates, abets, advises, or teaches, or a purpose of which is to engage in or to advocate, abet, advise, or teach, activities intended to overthrow, destroy or alter, or to assist in the overthrow, destruction or alteration of the constitutional form of the government of the United States, or of the state of Washington, or of any political subdivision of either of them, and to establish in place thereof any form of government the direction and control of which is to be vested in or exercised by or under, the domination or control of any foreign government, organization, or individual." WAsH. Rev. CoDE $\$$ g.8I.oro(3). See Baggett v. Bullitt, 215 F. Supp. 439 (W.D. Wash. 1963).

${ }^{79}$ WASH. Rev. CODE $\$ 28.70 .150$ and $\$ 28.76 .230$ (Supp. 1956). The specific problems of academic freedom raised by these oaths will not be separately treated in this article, but the general problems tend to be the same as those raised by disclaimer oaths. For further discussion of this type oath, see HENRY R. Linville, OAths of Loyalty for Teachers (1935), and Gardner \& Post, The Constitutional Questions Raised by the Flag Salute and Teacher's Oath Act in Massachusetts, I6 B.U.L. Rev. 803 (I936). It appears that the following states, in addition to Washington, require this type of oath from their teachers: Colorado, Indiana, Michigan, Nevada, New York, North Dakota and Vermont require these types of oaths as a condition of employment. See Fund for the Republic, Inc., Digest of the Public Record of Communism in THE UNITEd States, P. II, §M (I955). 
I solemnly swear (or affirm) that I will support the constitution and laws of the United States of America and the State of Washington, and will by precept and example promote respect for the flag and the institutions of the United States of America and the State of Washington, reverence for law and order and undivided allegiance to the government of the United States.

The legal sanctions behind oaths are two, one immediate and the other mediate. Failure to subscribe to the required oath generally means that an application for employment will automatically be denied or that a faculty member will lose his employment. The second sanction is the possibility of criminal prosecution and, perhaps, conviction for perjury. This second sanction, while less certain, is more severe. But given the continuing tensions of the cold war and the rise of the American radical right, ${ }^{73}$ with its emphasis on the educational system, it appears probable that there are now juries much more disposed to convict for false swearing than there once were. ${ }^{74}$ In addition, it now appears likely that voices will be raised which may insist that universities and/or state legislatures create and supervise a pattern of continuing investigation like that currently practiced by the federal government regarding its employees. The goal would be that of ferreting out false signers.

These recent developments will not, of course, serve to deter ambitious prosecutors, nor will the "expansive statutory definitions" of subversiveness. It appears that prospects of a possible conviction may have been in mind, when some witnesses, who in the early r940's clearly denied communist affliations, found it wise, in response to similar questions to plead their privilege against self-incrimination during the r950's. ${ }^{75}$ Even though a conviction might be uncertain, the mere hint of a threat of criminal prosecution is a sobering device and frequently enough to bring most academic people into line. Reputation, financial standing, advanced academic opportunities and social position are all at stake if a prosecution for falsely swearing to one's loyalty is started, regardless of its outcome. ${ }^{76}$ As the Supreme Court has observed, "people do not lightly disregard public officers' thinly veiled threats to institute criminal proceedings against them if they do not come around."77

The potentialities described above are hardly conducive to promoting that "sense of freedom" necessary for free and creative thought which, by definition, must challenge all existing orthodoxy. In such a situation the real result is, of course,

${ }^{73}$ See D. Bell (Ed.), The Radical Right (ig63); Mark Sherwin, The Extremists (ig63); R. Ellsworth \& S. Harrus, The American Right Wing (1962); I. Suall, The American Ultras (Ig6z); G. Gould, Inside the Birch Society (ig6i); First Nattonal Directory of Rigittist Groups (1962).

74 Consider, for example, Professor Koeninger's case, supra note 63 , and Board of Education $v$. Jewett, 2I Cal. App.2d 64, 68 P.2d 404 (1937) (classroom statements made by a teacher held to violate oath and constitute grounds for dismissal).

${ }^{75}$ Hearings Before the Subcomm. to Investigate the Administration of the Internal Security Act of the Sen. Comm. on the Judiciary, Subversive Influence in the Educational Process, 83d Cong., 1st Sess, 553-54 (I953).

${ }_{78}$ Alexander Hamilton saw this point clearly when he said that "a power over a man's subsistence amounts to a power over his will." The Federalist No. 79, at 49r (Gideon ed. 1818) (Hamilton). For discussion of the academic employment difficulties of "security risks," see chapter 7 of WALTER GELLHorN, LOYAITY AND SCIENCE 175-202 (1950).

${ }^{77}$ Bantam Books Inc. v. Sullivan, 372 U.S. $5^{8}$ ( 1963 ). 
an impairment of academic freedom. The sweep of recent events not only has a clear and distinct message for present faculty members but also for our youth who plan to seek out teaching positions. ${ }^{78}$ They must be fearful that they do not commit youthful indiscretions, or become involved in mistaken or misguided enthusiasms that later might rise from their pasts, like ghosts, to haunt their careers. They must not deviate; and hence, they must play it safe. Fearing later condemnation, they probably will shrink from associations, and therefore from speech and thought, that might stir controversy. ${ }^{79}$ On the other hand, if they do become entangled with a cause to the left of center, then their fears will be similar to those already present in many of today's faculty members. They will fear a continuing surveillance of their activities, or a combing of their pasts, or a cocking of ears, including those of their students, to catch all their words to sift them for clues of dangerous thoughts and badges of disloyalty. In short, loyalty oaths and their enforcement procedures cast a pall of orthodoxy over the classroom. There can be no academic freedom in such a situation. "Where suspicion fills the air and holds scholars in line for fear of

\footnotetext{
${ }^{78}$ Nor does it seem that college presidents are immune. Consider the case of Charles H. Fisher, President of Western Washington College of Education, who was dismissed after sixteen years of service. It appears that a committee of five citizens, including the local Grand Dragon of the Ku-Klux-Klan, submitted to the Board of Trustees ten charges against President Fisher which, having a modern ring, indicated that Fisher had allowed "numerous executives and members of subversive organizations, and of free love, atheistic and un-American pacifist organizations" to address the student body "while proAmericans have not appeared," and that he engaged in a "studied avoidance of having Christian leaders address the student body . . - while some lecturers who have appeared have spoken flippantly of Christianity and have condemned the American economic life." "The flag is seldom displayed on campus," and the student newspaper rebuked the local papers that warned the public against subversive activities. The Board of Trustees specifically dealt with each charge separately, and finally concluded by endorsing President Fisher. However, three years later he was dismissed by the same trustees without any additional reasons being given. It should be noted that immediately after the trustees' first decision, the chairman of the citizens' group appealed to Governor Martin who conferred with the Board before its second decision. Reported in 27 AAUP Bulletrin 48 (I94I).

${ }^{70}$ John Stuart Mill's classic point applies here:

"[T] $T$ he peculiar evil of silencing the expression of an opinion is that it is robbing the human race; posterity as well as the existing generation; those who dissent from the opinion, still more than those who hold it. If the opinion is right, they are deprived of the opportunity of exchanging error for truth: if wrong, they lose, what is almost as great a benefit, the clearer perception and livelier impression of truth, produced by its collision with error." John Stuart MiLl, ON Liberty I6 (Crofts Classics ed.
} 1947).

${ }_{80}$ Consider the remarks of Paul F. Lazarsfeld \& Wagner Thielens, The Academic Mind ior (1958):

"Men and women who opposed Communism may find it quite degrading if they feel forced to reiterate their private convictions in order to satisfy suspicious critics. While they agree with the condemnation of Communism, they fear they may be setting a dangerous precedent on the broader issue of free expression of opinions. If forswearing heresy becomes general practice, they may someday find themselves in a precarious position if they should deviate from the prevailing mood of the time. As a result, professors often feel embarrassment and even guilt. They are not extremists, but they dislike having to prove it."

In the years following World War II, when intellectual liberty has been so much under attack, this study by Lazarsfeld and Thielens shows that: (a) $46 \%$ of the teachers covered by their study felt "apprehensive" about their freedom to teach and speak freely (id. at 84-85). But, significantly, a higher percentage, $54 \%$, of those without tenure felt the apprehension (id. at 240 ); (b) this "apprehension" put "a noticeable damper on the activities and opinions" of these teachers (id. at 192); (c) some teachers toned down their writings and did not fully express their full convictions and thought in their writings and avoided assigning "controversial" reference works for discussion (id. at 197); (d) some teachers avoided 
their jobs, there can be no exercise of the free intellect." ${ }^{81}$ Fear replaces the pursuit of knowledge with deadening doctrines; discussion ends where it should begin, and "supineness and dogmatism take the place of free inquiry."

III

\section{ACademic Freedom, Loyalty Oaths, and the Constitution}

There is an inevitable clash between loyalty oaths, as state-prescribed conditions for university employment, and academic freedom which, ultimately, must be governed by the Constitution. To date, the United States Supreme Court has not fully explored any case which has unequivocally pitted the first amendment claim of a faculty member to free speech, including academic freedom, against a state requirement that, as a condition of employment, a professor must subscribe to a loyalty oath. It should be recalled that recognition of the fact that academic freedom will be given first amendment protection is of comparatively recent date, coming in the Sweezy case, supra. Since that case, the Court has written opinions in only two loyalty oath cases, neither of them involving a claim to academic freedom. ${ }^{88}$ Thus, it can be seen that critical investigations must be undertaken and that the relevant constitutional doctrines remain to be formulated and are still in the process of being settled. Even so, the doctrines will, in part, be forged from the precedents.

Before turning to the relevant cases, ${ }^{84}$ one shibboleth ought to be buried for all time. It is the assertion that a public employee has no standing to complain about a loyalty oath, as a condition of employment, for the reason that his public employment is a privilege and not a right. If this "privilege vs. right" fallacy were carried to its logical conclusion, it would disallow all applications of the fourteenth amendment to test the conditions of state employment, thereby nullifying that amendment in this area. States would be free to condition their employment on such constitutionally forbidden criteria as race, religion, or politics because, after all, none would be denied any rights if public employment were simply a privilege. ${ }^{85}$

Is public employment merely a "privilege" such that it can arbitrarily be denied, and need not public officials present a rational basis for such denials? The answer

controversial subjects in the classroom (id. at 197); (e) for some, their relationships with students were substantially impaired (id. at 204 f). This state of affairs ought to be compared with Justice Frankfurter's view that ". . . the liberty of man to search for truth ought not be fettered, no matter what orthodoxies he may challenge." Dennis v. United States, 34 I U.S. 494, 550 (1950).

${ }^{81}$ Per Douglas, J., in Adler v. Board of Education, 342 U.S. 485, 510 (1951).

${ }^{82}$ Ibid.

${ }^{83}$ Speiser v. Randall, 357 U.S. 5 I3 (1958), and Cramp v. Florida, 368 U.S. 278 (I962).

84 Although important to a legal analysis of loyalty oaths, but not directly to academic freedom, I will not deal with the Bill of Attainder cases: Cummings v. Missouri, 7I U.S. 227 (1866); Ex parte Garland, 7r U.S. 333 (I866); Pierce v. Carskadon, 83 U.S. 234 (1872), nor with American Communications Ass'n v. Douds, 339 U.S. 382 (1950). These, and other cases, have recently been the subject of an excellent discussion. See Comment, The Bounds of Legislative Specifications: A Suggested Approach to the Bill of Attainder Clause, 72 YALE L.J. 330 (1962).

${ }^{85}$ Much confusion has resulted from a taking out of context of Mr. Justice Holmes' remarks in McAuliffe v. City of New Bedford, I55 Mass. 216, 220, 29 N.E. 5I7 (I892), where he said, "The petitioner may have a constitutional right to talk politics, but he has no constitutional right to be a policeman." 
is clear. Although some lawyers, and courts, ${ }^{86}$ have refused to accept it, the Supreme Court has set this issue at rest: $:^{87}$

We need not pause to consider whether an abstract right to public employment exists. It is sufficient to say that constitutional protection does extend to the public servant whose exclusion pursuant to a statute is patently arbitrary or discriminatory.

This fundamental principle applies beyond public employment to public offices for the Court has held that "the fact ... that a person is not compelled to hold public office cannot possibly be an excuse for barring him from office by stateimposed criteria forbidden by the Constitution." 88

Garner v. Board of Public Works $s^{89}$ was the first case in which the Court wrote an opinion on the constitutional status of state power to condition employment on the execution of a modern disclaimer oath. California required that, as a condition of employment, every employee must execute an affidavit stating whether or not he was a member of the Communist Party, U.S.A., and, if so, must state the dates of his membership. ${ }^{90}$ In addition, each employee was required to take a disclaimer oath. ${ }^{91}$ Fifteen civil service employees of the City of Los Angeles refused to subscribe to the oath, and two others, who took the oath, refused to execute the affidavit. They argued that these requirements violated their constitutional rights in that they transgressed constitutional prohibitions against Bills of Attainder, ex post facto laws, and state deprivations of speech and assembly. By votes of 7-to-2 on the affidavit and 5 -to-4 on the disclaimer oath, the Court upheld both measures over all objections.

Relevant to a discussion of academic freedom ${ }^{92}$ is the fact that in his opinion for the Court, Mr. Justice Clark did not, in any way, explore or discuss the constitutional relationships between the oath or affidavit and the first and fourteenth amendments. Instead, he described the situation presented by Garner in very restrictive terms, characterizing the oath requirement as a provision reasonably designed to protect the integrity and competency of the municipal civil service through reasonable inquiry into the qualifications of persons to learn their fitness for employment. Since the Court earlier had upheld a similar provision when applied to federal civil servants, ${ }^{93}$ then, on precedent, "a State is not without power to do as much."94 In addition to precedent, the Court reasoned by analogy from the fact that since

${ }^{\text {so }}$ See, e.g., Gnecchi v. Washington, 58 Wash.2d 467, 364 P.2d 225 (I961).

${ }^{87}$ Wieman v. Updegraff, 344 U.S. $x 83$, x92 (x952); see Slochower v. Board of Higher Education, 350 U.S. 55 I (I956).

${ }^{88}$ Torcaso v. Watkins, 367 U.S. $488,495-96$ (196r); this view was recently confirmed in Cramp v. Florida, 368 U.S. 278, 288 (1962).

${ }^{80} 34$ I U.S. 716 (195I). An carlier case, Gerende v. Board of Supervisors, 34I U.S. 56 (I95I), was disposed of per curiam and applied to political offices.

${ }^{\circ 0}$ The similarity of this question to that of the Barenblatt case is obvious.

${ }^{01}$ Its provisions were not as expansive as those appearing in note 71 supra, but somewhat similar.

${ }^{93}$ I do not discuss the Bill of Attainder or ex post facto points.

${ }^{03}$ United Public Workers v. Mitchell, 330 U.S. 75 (1947).

- Garner v. Board of Public Works, 34I U.S. 716, 721 (195I). 
private industry frequently inquired into loyalty, past conduct, and associational relationships to determine fitness for private employment, such inquiry should be no less relevant for public employment. This last point appears spurious to the extent that public employment is, and private industry is not, bound by the fourteenth amendment, but, as indicated above, the Court made no explorations of the limitations of the first and fourteenth amendments in the Garner case. Thus, it can be seen that the Court adjudicated only the interests of the state and the employee solely with regard to the integrity of the civil service.

Garner certainly does not consider the interests of a state or those of a professor in academic freedom on a university campus, and the case does not speak to this set of relationships. That the interest of both a state and an employee in the municipal civil service differs significantly from a state's interest in its faculty and a professor's interest in employment at a university cannot be denied. Furthermore, there is no precedent squarely speaking to this point; the issue of pitting claims of constitutional protection for academic freedom against the claims of a state to prescribe loyalty oaths as conditions of academic employment has not been foreclosed by the Garner case. ${ }^{95}$ Moreover, whatever interest a state may have which justifies it in restricting the speech and associations of its civil servants as a condition of their employment is, obviously, not of the same order as its interests regarding the speech and associations of university faculty members. ${ }^{96}$ To the contrary, the legitimate interest of a state in a free society, and the interest of a faculty member, at a free university, are not in conflict, but in harmony; they join together to further free speech and associations of faculty members and thereby to encourage the pursuit of truth and knowledge for the entire community.

A case, decided before Sweezy, appears to contradict this view. Adler v. Board of Education ${ }^{97}$ is not a loyalty oath case, but it is relevant because it asked the Court to pass on the constitutionality of a scheme to counteract what was called "subversive" influences in New York's public school system. Since I940, the Civil Service Law of New York has disallowed persons from teaching in any public school if they were currently members of organizations that advocated the overthrow of government by force and violence. In I949, an amendment provided that, after holding hearings, the Board of Regents was to prepare a list of banned organiza-

${ }^{95}$ The Court has recognized this point in a subsequent case where it distinguished the Gerende and Garner cases on the ground that in those cases there was "... no attempt directly to control spcech but rather to protect from an evil shown to be grave, some interest clearly within the sphere of governmental concern. . . ." See Speiser v. Randall, 357 U.S. 513, 527 (1958).

${ }^{\circ \circ}$ Three considerations have been put forth as justifications for applying loyalty oaths for all academic employment. They are that ( $\mathrm{r}$ ) a Communist teacher has no independent judgment and is subservient to the party line, (2) he is committed to the destruction of freedom, including academic freedom, (3) the Communist teacher is a member of a criminal conspiracy. After painstaking analysis of these considerations, Professor Brown concludes that the "fact that most teachers are public employees makes them especially vulnerable to loyalty tests on the grounds advanced with respect to civil servants. On the other hand, this is a field in which no valid security considerations exist, except in areas of applied military research that are not primarily part of the business of seeking and transmitting knowledge." RALPH S. BROWN, LOYALTY AND SECURITY 333-38, 339 (I958).

${ }^{97} 342$ U.S. 485 (1952). 
tions and to make membership in any of them prima facie evidence of ineligibility for continued public school employment. Four teachers ${ }^{98}$ attacked the constitutionality of the 1949 amendment, arguing that it denied them due proecss of law ( $\mathrm{I}$ ) by abridging their rights to freedom of speech and association, and (2) by the use of the presumption which created a prima facie case of disqualification against a teacher, thereby shifting the burden of proof. By a 6-to-3 vote, the Court upheld these statutory provisions as constitutional.

In his opinion for the Court, Mr. Justice Minton relied on the now discredited theory that state employment was a "privilege" and not a "right." Reg Regarding the second argument of the teachers, the Court held that membership in a suspected organization could properly be relied upon to constitute prima facie grounds for dismissal without there being a violation of due process. The presumption was not conclusive, and there was no shifting of the burden of proof. The majority view was that the relation between the found fact (membership) and the legally presumed fact (evidence of disqualification) was "clear-and-direct," but not conclusive, and hence, simply a rule of evidence. The statute required that teachers be given a hearing before their employment could be terminated. In this situation then, "the requirements of due process are satisfied." This point appears to have been overruled, sub silentio, by $S$ peiser v. Randall. ${ }^{100}$ This means then, that only the first portion of the case remains to be considered.

The Court's opinion dealt with the first and, for purposes of academic freedom, the important, question in the Adler case. It was whether teachers could be discharged due to their unexplained membership in an organization which the Board of Regents had listed as one which taught or advocated the doctrine of violent overthrow of government. Justice Minton cited and relied upon the Garner case as the Court's sole support for an affirmative answer to this question.

The precedential faith of the Court in the Garner case appears embarrassingly misplaced for several reasons. First, Garner expressly reserved judgment on the point for which the Court cited it: ${ }^{101}$

Not before us is the question whether the city may determine that an employee's disclosure of such political affiliation [in the Communist Party, U.S.A.] justifies his discharge.

The Garner case spoke only to the question whether, as a condition of employment, a state's interest in the integrity of its civil service justified an inquiry, by means of disclaimer oath and affidavit, into a civil servant's associations. Since Garner did not explore the relationships of such an inquiry to fundamental freedoms protected by the first and fourteenth amendments, reliance upon it appears doubly misplaced in Adler's academic freedom context.

${ }^{08}$ Also, as plaintiffs, there were two parents and two taxpayers.

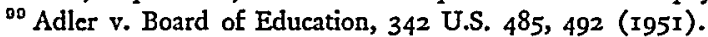

${ }^{100} 357$ U.S. 513 (1958). The case is discussed infra at 507-08.

${ }^{101}$ Garner v. Board of Public Works, 34I U.S. 7I6, 720 (I95I). It is true that the majority did uphold the discharge of Pacifico and Schwartz, id. at 724, but it did so without discussion or a vote on the issue. 
In addition, Garner reasoned by analogy from the type of inquiry conducted by private industry and held that a similar inquiry would be proper into the associations of municipal civil servants. ${ }^{102}$ Except for limitations imposed by the fourteenth amendment on state action, perhaps this approach is reasonable because some conditions in private industry and the civil service are analogous. However, the necessary conditions of academic freedom for the proper functioning of our universities and schools are certainly not analogous to those necessary for the continued functioning of private industry or the civil service. Thus, it is to be regretted that, by a simple citation to precedent, and without a careful exploration of the underlying vital interests, the Court, unwittingly, decided in the Adler case an issue presenting considerations of academic freedom fundamentally different from those found in the precedential cases. Consequently, Adler leaves much to be desired in both reason and judgment and cannot be considered determinative of the academic freedom issues presented when loyalty oaths are made a condition of university employment.

A later case, Wieman $v . U_{p d e g r a f},{ }^{103}$ makes it patently clear that if an employee is under threat of discharge for failure to subscribe to an oath regarding his speech and associations, then the character of those associations must be known to him. Innocent or ignorant membership will not suffice; otherwise there would exist guilt by association. One must know, not only of his own membership in the banned organization, but also what its true purposes actually are, and any oath not providing that the affiant possess scienter is constitutionally defective. Another case requires that a hearing must be afforded an employee to determine whether he actually had this knowledge. ${ }^{104}$ Furthermore, recent cases suggest that before a conviction, or, perhaps, a discharge from public employment, can be based on prohibited associational membership, not only must an employee's membership be "knowing" in the sense described above, but, in addition, it must also be "active." It must be active in the sense that the member, personally, must have engaged in promoting the prohibited purposes, i.e., the overthrow of government by force and violence. ${ }^{105}$ Thus, it appears that the course of subsequent events has corroded the vitality of the Adler case.

Recent cases demonstrate a changed attitude in the Court. It seems that now it will explore and be more sensitive to the interests not considered in Adler. The

\footnotetext{
102 "Past conduct may well relate to present fitness; past loyalty may have a reasonable relationship to present and future trust. Both are commonly inquired into in determining fitness for both high and low positions in private industry and are not less relevant in public employment." Garner v. Board of Public Works, 341 U.S. 716, 720 (1951).

${ }^{103} 344$ U.S. I83 (1952).

${ }^{104}$ Slochower v. Board of Education, 350 U.S. 55 I (1956); Norstrand v. Little, 368 U.S. 436 (1962). But compare Beilan v. Board of Education, 357 U.S. 399 (1958); Lerner v. Casey, 357 U.S. 468 (1958); Nelson v. Los Angeles County, 362 U.S. I (1960); Cohen v. Hurley, 366 U.S. II7 (1961); Konigsberg v. State Bar of California, 353 U.S. 252 (1957), 366 U.S. 36 (I96r), and In re George Anastaplo, 366 U.S. 82 (196r).

${ }^{105}$ See Scales v. United States, 367 U.S. 203 (I96r), and Noto v. United States, 367 U.S. 290 (196r).
} 
first case demonstrating this perspective is Speiser v. Randall, ${ }^{106}$ which arose in this way. In 1952 California amended its constitution and attached disabilities to those persons who advocate the doctrine of violent overthrow of government; the disabilities included the denial of specific tax exemptions. ${ }^{107}$ By way of implementing this measure, a California statute was passed which required a disclaimer oath of non-advocacy from all taxpayers seeking a property tax exemption. This measure almost reaches the absurdity of requiring a loyalty oath of every citizen. Two World War II veterans declined to take the oath; they were denied the tax exemption and brought suit, arguing that the denial of the tax exemption was unconstitutional and deprived them of due process. On appeal, the United States Supreme Court agreed.

The importance of the Speiser case lies not in its treatment of the first amendment issue directly, ${ }^{108}$ but rather in its procedural point as it relates to freedom of speech and association. In his opinion for the Court, Mr. Justice Brennan noted that California had placed the burden of proof upon the taxpayers to show that they were entitled to the tax exemption. This burden was not satisfied when taxpayers executed the oath, "but throughout the judicial and administrative proceedings the burden lies on the taxpayer."109 Given this procedure, the question for decision was whether California constitutionally could use it as a means of locating those people who do, in fact, advocate the prohibited doctrines. ${ }^{110}$ By a vote of 7 -to-I, the Court held that this procedure could not be used. The line between legitimate and illegitimate expression is shadowy at best, and there always is some degree of error inherent in legal procedures. Thus, where "the transcendent value of speech is involved, due process certainly requires in the circumstances of this case that the state bear the burden of persuasion to show that the appellants engaged in criminal speech."111

But, significantly, the unconstitutional vice in the California procedure was not simply that of allowing for an occasional error in denying a tax exemption, and thereby penalizing legitimate speech. Rather, the vice of the procedure lay in its practical operation. If a man "knows that he must bring forth proof and persuade another of the lawfulness of his conduct necessarily [he] must steer far wider of the unlawful zone than if the State must bear these burdens."112 Thus, California's procedure was constitutionally defective. "It can only result in a deterrence of speech

${ }^{100} 357$ U.S. 513 (1958), but compare, Konigsberg v. California, 366 U.S. 36 (196r). I am indebted here to Kalven \& Steffen, The Bar Admission Cases, 2I LAw In Transition I55 (I96I).

${ }^{207}$ Cal. Const. art. 20, $\$ 19$.

${ }^{108}$ Indeed, the Court assumed ". . without deciding that California may deny tax exemptions to persons who engage in the proscribed speech for which they might be fined or imprisoned." Speiser v. Randall, 357 U.S. 513, 520 (1958).

${ }^{100}$ Id. at 522.

${ }^{110} \mathrm{Id}$. at 523 . "The question for decision, therefore, is whether this allocation of the burden of proof, on an issue concerning freedom of speech, falls short of the requirements of due process."

321 Id. at 526 .

112 Ibid. 
which the Constitution makes free."113 In summary, the "procedure, therefore, is bad because it places an unconstitutional burden on free speech"; ${ }^{114}$ hence, the veterans, in this case, could not be denied a tax exemption for refusing to take the first step-the oath-in an invalid series.

The implications of Speiser for the Adler case are obvious enough; but what is exceptional about the Speiser case is its deep commitment to the values found in freedom of speech and association. In addition, since it did involve a loyalty oath, the Speiser decision may have marked a shift in the attitude of the Court regarding the extent to which a state may go when inquiring into a person's speech and associations as a condition of granting a tax exemption, or perhaps, as a condition of employment.

Shelton v. Tucker, ${ }^{115}$ discussed above, ${ }^{116}$ was decided two years after Speiser and appears to maintain the Court's commitment to free speech, specifically including intellectual liberty. It also shows that the Court is sensitive indeed to the issues ignored in Adler. The Shelton case in some way goes beyond Speiser and declares that, where free speech and association are concerned, due process requires that "the operation and effect of the method by which speech is sought to be restrained must be subjected to close analysis and critical judgment in the light of the particular circumstances to which it is applied."117

Considered in conjunction with Speiser, Shelton can have significant implications for the blunderbuss approach of loyalty oaths as a means of ferreting out "subversives." The logical extension of these two cases, plus a consideration of the intellectual values discussed in Sweezy, may mean that, at least in so far as academic employment is concerned, loyalty oaths will be disallowed as conditions of employment. The Supreme Court may require that states use a more selective technique. Another consideration tends to support this conclusion. Apart from the fact that oaths are utterly inconsistent with meaningful professorial employment, the Court has recognized in Shelton, unlike Adler and Garner, that notwithstanding a legitimate state interest, inquiries imposed as a condition of employment are subject to the limitations of the first and fourteenth amendments. The Court held that, "even though the governmental purpose be legitimate and substantial, that purpose cannot be pursued by means that broadly stifle fundamental personal liberties when the end can be more narrowly achieved."118 Thus, it appears possible that the blanket approach-that is, using loyalty oaths to ferret out subversives-may be found to be constitutionally incompatible with the necessary conditions required for academic employment.

At the minimum, Shelton indicates that the Court carefully will measure the

113 Ibid.

114 Kalven \& Steffen, The Bar Admission Cases, 2I IAw in Transimon 155, r8r (I96r).

${ }^{118}{ }_{36}$ U.S. 479 (1960).

110 See discussion supra at $494-95$.

${ }^{117}$ Shelton v. Tucker, 364 U.S. 479,520 (1960).

${ }^{118}$ Id. at 488 . 
sweep of an oath to determine whether the breadth of its wording goes beyond the pale of constitutional permissibility. ${ }^{119}$ When coupled with a point in Speiser, Shelton foreshadows an unhappy constitutional future for loyalty oaths which are indiscriminate in their expansiveness. Speiser granted as one of its basic premises. the assumption that a state may condition its tax exemptions in such a way as to deny them "to persons who engage in the proscribed speech for which they might be fined or imprisoned." I20 If this assumption is followed in cases dealing with state power to prescribe loyalty oaths as conditions for employment, then a state has power to condition academic employment only on the ground that a professor disclaim advocacy of speech which that state could criminally punish and no more. In short, this means that the reach of state loyalty oaths would be measured by the standards set forth in the Smith Act cases. ${ }^{121}$ Consequently, lower courts. would have guidelines which would enable them to carry out the Supreme Court's. mandate in Shelton that the "breadth of legislative abridgment must be viewed in the light of less drastic means for achieving the same basic purpose."122

The opinion in the last loyalty oath case decided by the Court ${ }^{123}$ corroborates its. sensitivity to the values of free speech exhibited in Speiser. This case establishes another constitutional fence beyond which loyalty oaths may not venture. Cramp, a school teacher for nine years, refused to sign Florida's loyalty oath as a condition of his continued employment. ${ }^{124}$ The oath would have required him to swear that he had never lent his "aid, support, advice, counsel or influence to the Communist Party."125 Cramp brought an action for a declaration that the oath was unconstitutional and that its application to him be enjoined. The Florida courts upheld the oath-statute over an argument that it was so vague as to deny due process of law. On appeal, the United States Supreme Court reversed by a vote of 9-to-o. ${ }^{126}$

Cramp v. Florida establishes that before an oath can pass constitutional muster it must be cast in terms that are "susceptible of objective measurement."127 When oaths do not reach this standard, but are cast in terms that are fluid and indefinite, the Court observed that two evils can, and do, occur. On the one hand, the vice of unconstitutional vagueness requires that a man speak and associate at his peril; it thereby operates to deter the exercise of individual freedoms and has a potentially

\footnotetext{
110 "The unlimited and indiscriminate sweep of the statute now before us brings it within the ban of our prior cases." Id. at 490.

${ }^{120}$ Speiser v. Randall, 357 U.S. 513, 520 (1958).

${ }^{121}$ See, e.g., Noto v. United States, 367 U.S. 290 (I96I); Scales v. United States, 367 U.S. 203 (I96I); Yates v. United States, 354 U.S. 298 (I957); Dennis v. United States, 34I U.S. 494 (I95I).

123 Shelton v. Tucker, 364 U.S. 479,488 (I960). Also see Louisiana v. NAACP, 366 U.S. 293, 296 (196r), where the Court said that "in an area where, as Shelton v. Tucker, 364 U.S. 479, emphasized, any regulation must be highly selective in order to survive challenge under the First Amendment."

${ }^{123}$ Cramp v. Florida, 368 U.S. 278 (I96r). See Note, 34 Rocky MT. L. REv. 548 (I962).

124 Refusal to sign resulted in an employee's immediate discharge. FLA. Stat. $\$ 876.08$ (I953).

${ }^{125}$ FLA. STAT. \$ 876.05 (I953).

${ }^{120}$ Cramp v. Florida, 368 U.S. 278 (1962).

${ }^{127}$ Id. at 286.
} 
inhibiting effect on speech. Thus, "the free dissemination of ideas may be the loser."128

On the other hand, unconstitutional vagueness of an oath carries another vice. It requires that a man must speculate as to the nature of penal laws that may be applied to him in a perjury trial. "It is not the penalty itself that is invalid but the exaction of obedience to a rule or standard that is so vague and indefinite as to be really no rule or standard at all."129 Due process of law requires that a man be given clear notice of that speech and those associations which have been prohibited; and stricter standards of clarity apply to laws which have a potentially deterring impact on freedom of speech.

In its discussion of this last point-possible perjury prosecution-the Court was careful to note that the compulsion of an oath "might weigh most heavily upon those whose conscientious scruples were the most sensitive."130 Evidence has been found suggesting the truth of this view and that people of principle and high conscience, and not communists, are the ones who refuse to subscribe to loyalty oaths and are the ones most likely to run the risks of perjury actions. ${ }^{131}$ Additionally, as though in realization of the significance of the rise of the American right wing, the Court said that it "would be blinking reality not to acknowledge that there are some among us always to affix a communist label upon those whose ideas they violently oppose."132 And, after all, "experience teaches that prosecutors too are human."133

While the Cramp opinion is not particularly helpful in determining precisely what terminology would be "susceptible of objective measurement," it does provide an example of terms which fail to meet the standard. ${ }^{\mathbf{1 3 4}}$ Its importance is two-fold: First, it suggests that the Court is willing to take a new look at loyalty oaths as a condition of employment and is no longer satisfied to decide cases by simple citation of precedent such as Garner and Adler. Secondly, the Court has established another boundary for loyalty oaths; namely, that they must be susceptible of objective measurement.

\section{Conclusion}

The requirements, by a state, that its teachers and researchers execute a loyalty oath, as a condition of their employment, reflects a basic misunderstanding of the

${ }^{13 s} I d$. at 287 .

${ }^{120} I d$. at 286 .

$130 \mathrm{Id}$. at $286-87$.

${ }^{131}$ See Byse, $A$ Report on the Pennsylvania Loyally Act, ror U. PA. L. REv. 480,482 n.5 (1953). At California, twenty-six members of the faculty were dismissed for refusing to sign and thirty-seven more resigned in protest. There is no evidence indicating that any one of them was a communist. See CommiT. tee on Academic Freedom, Interim Report to the Academic Senate, Northern Section of University of California (I951), and George R. Stewart, The Year of the Oath (I950).

${ }^{182}$ Cramp v. Florida, 368 U.S. $278,286-87$ (r962).

${ }^{183} \mathrm{Id}$, at 287 .

${ }^{184}$ The Court seems to suggest that, perhaps, an oath might inquire into advocacy of violent overthrow of government or "membership or affliation with the Communist Party." Id. at 286. On vagueness, sce Note, The Void-for-Vagueness Doctrine in the Supreme Court, tog U. PA. L. REv. 67 (1960). 
educational process. It is idle to shirk the fundamental issue involved, for upon its resolution turns not only the future of loyalty oaths but the course of education itself. The fundamental cleavage is simply this: there can be no agreement between those people who regard education as a means of instilling and propagating certain definite and approved beliefs, ${ }^{135}$ and those other people who think that, above all else, education should produce a disciplined and critical mind with the power of independent judgment.

Those people who prescribe loyalty oaths as a condition of academic employment, consciously or unconsciously, lend their support to the first view. They are clearly disturbed by the threats to the future of our society which derive from our presently divided world. No one can be complacent on this matter; there has been nothing quite like it in our previous history. Our institutions of liberty are being called

${ }^{130}$ Compare Zechariaf Chafee, The Blessings of Liberty 241 n.2 (1956): "The government pays judges, but it does not tell them how to decide. An independent . . . university is as essential to the community as an independent judiciary."

A direct attack upon academic freedom, and upon meaningful education itself, has been mounting. This is evidenced by the following statute. FLA. StAT. $\S 230.23$ :

"Americanism us. communism: required high school course.-1. The legislature of the state hereby finds it to be a fact that

"a. The political ideology commonly known and referred to as communism is in conflict with and contrary to the principles of constitutional government of the United States as epitomized in its national constitution.

"b. The successful exploitation and manipulation of youth and student groups throughout the world to-day are a major challenge which free world forces must meet and defeat, and

"c. The best method of meeting this challenge is to have the youth of the state and nation thoroughly and completely informed as to the evils, dangers and fallacies of communism by giving them a thorough understanding of the entire communist movement, including its history, doctrines, objectives and techniques.

"2. The public high schools shall each teach a complete course of not less than thirty hours, to all students enrolled in said public high schools entitled 'Americanism versus communism.'

"3. The course shall provide adequate instruction in the history, doctrines, objectives and techniques of communism and shall be for the primary purpose of instilling in the minds of the students a greater appreciation of democratic processes, freedom under law, and the will to preserve that freedom.

"4. The course shall be one of orientation in comparative governments and shall emphasize the freeenterprise-competitive economy of the United States as the one which produces higher wages, higher standards of living, greater personal freedom and liberty than any other system of economics on earth.

"5. The course shall lay particular emphasis upon the dangers of communism, the ways to fight communism, the evils of communism, the fallacies of communism, and the false doctrines of communism.

"6. The state textbook committee and the state board of education shall take such action as may be necessary and appropriate to prescribe suitable textbook and instructional material as provided by state law, using as one of its guides the official reports of the House Committee on Un-American Activities and the Senate Internal Security Sub-committee of the United States Congress.

"7. No teacher or textual material assigned to this course shall present communism as preferable to the system of constitutional government and the free-enterprise-competitive economy indigenous to the United States.

"8. The course of study hereinabove provided for shall be taught in all of the public high schools of the state no later than the school year commencing in September 1962. Laws r96I, c. 6I-77, \$\$ I-7, 9."

In r962, Louisiana passed a similar statute directing the state department of education, in conjunction with the local school systems, to conduct seminars for "certain teachers and eleventh and twelfth grade high school students ...." The purpose of the seminars is to give their participants "a clear understanding of the fundamental principles of the American form of government, the evils of socialism and the basic philosophy of communism and the strategy and tactics used by the Communists in their efforts to achieve their ultimate goal of world domination." The statute does not say who the seminar teachers will be, nor what materials shall be used. See LA. StAT. ANN. R.S. $\$ \$ 2851,2852$. For accounts of more subtle attacks on academic freedom, see Jack Nelson \& Gene Roberts, The Censors and the Schools ( 1963 ). 
into question, and should they fall, totalitarianism would rule our homes. In their fervor to cope with what they perceive as the threat to our free institutions, our state legislatures appear to have acted on the theory that the only source of attack is from "communism." They have commonly adopted a method to deal with these threats which is, simply, that of finding some means whereby one can be assured that an employee's attitude will favor "Americanism" against communism. ${ }^{130}$ Thus, our legislatures usually have enacted loyalty-security programs which, at the state level, means a heavy reliance upon loyalty oaths. Their aim is to insure the employment of people who espouse "Americanism." It is believed that in this way our institutions of liberty can be saved and perpetuated.

A general exror of those men who prescribe loyalty oaths as the appropriate means of dealing with communism is that they confuse loyalty with mere orthodoxy. Being negatively defined as anti-communism, this concept of "loyalty" suffers from a provincial myopia. ${ }^{137}$ There has been a shift to negativism, and it reveals a terrible fear and distrust which are expressions of the insecurity of our times. Today, anticommunism is dangerously becoming as doctrinaire as communism itself-and may come to embrace the root evil of totalitarianism, intolerance. ${ }^{138}$ Inherent in the anti-communist definition of "loyalty" is the notion that dissent and cultural diversity can no longer be broadly tolerated. The boundary line between vigorous dissent and communism has become shadowy. This dividing line and the tensions it develops are further aggravated by oaths. ${ }^{139}$ The reason is that, in their zeal to be sure that they have dealt fully with the problem, state legislatures have cast their loyalty-oath definitions of anti-communism into loose and general terms. Thus, the net of orthodoxy spreads. ${ }^{140}$ However, as Thomas Jefferson carefully pointed out, toleration of error is the inescapable condition of the pursuit of truth.

When legislatures require loyalty oaths as conditions for academic employment,

${ }^{136}$ See, Mundt, The Case for the McCarran Act, in Selected Readings, AMherst College, Loyalty in a Democratic State 69 (I952), and compare Truman, The Internal Security Act: Velo Message, id. at 77 .

${ }^{137}$ See A. Barth, The Loyalty of Free MEN (r95I). The theme of a multiplicity of loyalties is capably analyzed in Morton Grodzins, The Loyal and the Disloyal: Social Boundaries of Patriotism AND TREASON (1956).

${ }^{138}$ See materials in note 73 supra.

${ }^{139}$ Two examples from Paul Lazarsfeld \& Wagner Thielens, The Academic Mind (x958), illustrate the way in which oaths invade and intimidate professors. At page 223 they report an interview as follows.

"'In the present state of affairs, I won't join any political group. Almost any group that is trying to protect what it thinks is civil liberties, I think could end up on the Attorney General's list. I know for a fact that in the past contributions by check to certain organizations were photographed, and it goes. on now. I send no checks to such things." "

And the other example:

"In explaining his avoidance of political organizations, a respondent who grew up in Nazi Germany saw a parallel between the current scene and the experiences of his youth:

"I 'I don't belong to any and I would be very hesitant to join any. I learned this in Germany in high school. Never join any group at all. This isn't a case of lack of interest, but experience that something might turn against you, because in ten years if you join any organization someone might say this was. subversive." "

${ }^{110}$ See, Samuei A. Stouffer, Communism, Conformity and Civil Liberties (1955). 
they express a fundamental ambivalence toward education. On the one hand, they want to be sure that, in the present conflict with totalitarianism, our schools and universities will remain free and courageous in pursuit of truth, thereby developing conditions necessary for an exercise of critical and independent judgment. Yet, on the other hand, our state legislatures have done a curious thing. They have tried to reach this goal by controlling the mind of the professor, insisting that the teachers and researchers who populate our academic institutions possess basic opinions and attitudes favoring "Americanism," variously defined as "anti-subversive." Somehow the necessary assumptions, unsupported by evidence, appear to be that our colleges and schools are staffed to some degree with advocates of armed revolt, and that, if let alone, our boards of regents and personnel committees will employ teachers, and even secretaries, who spread the doctrine of violent overthrow of government. The dominant thrust of legislative action has been to promote the view that education is a means of instilling certain definite and approved beliefs and opinions while, at the same time, trying to give some credence to the thoughts expressed by the Supreme Court in West Virginia v. Barnette: ${ }^{141}$

If there is any fixed star in our constitutional constellation, it is that no official, high or petty, can prescribe what shall be orthodox in politics, nationalism, religion or other matters of opinion or force citizens to confess by word or act their faith therein.

That both of these views cannot survive is obvious. They come into focus when state-prescribed loyalty oaths, as a condition of academic employment, are confronted with the constitutional protection afforded academic freedom. This issue remains for the Court to resolve. It seems clear that the balance must be struck in favor of academic freedom. In educational terms, it is known that the values of a free society can be achieved only by the use of methods consistent with freedom, and that, currently, instruction along these lines is woefully inadequate. ${ }^{142}$ The attempt to teach democratic values by means of indoctrination and propaganda has been held to have the vice of unconstitutionality within it. ${ }^{143}$ The same considerations ought to prevail in the equally fundamental area of teacher selection where the only criteria should be, simply, intellectual competence, sincerity, a deep concern for human welfare, and a tolerance rooted in humility. Knowledge wielded by love is what our society needs; loyalty oaths do not achieve this goal.

Should the Court strike the balance in favor of academic freedom, it would allow for the realization of the advice of Thomas Jefferson when he said that a university should be based "on the illimitable freedom of the human mind . . . we are not afraid to follow truth wherever it may lead, nor to tolerate any error so long as reason is left free to combat it."144 Loyalty oaths repudiate Jefferson's understanding.

${ }_{141}^{149}$ 319 U.S. 624,642 (1943).

${ }^{143}$ Sce, Report of the Williamstown Workshop: A Procram for IMproving Bitl of Rights TeACHING IN High Schools (rg62).

${ }_{123}$ West Virginia v. Barnette, 319 U.S. 624 (1943).

1447 The Writings of Thosias Jefrerson 196 ( $\mathrm{H}$. A. Washintgon ed. 1853-54). Cf. xo The Wrutings 
The agents of communism have done nothing to our universities and schools which is potentially more dangerous than what, out of fearful insecurity, they have induced us to do to ourselves. "To strike freedom of the mind with the fist of patriotism is an old and ugly subtlety. ${ }^{145}$ It is contrary to our basic principles and fundamental institutions. ${ }^{148}$ The Constitution guarantees freedom of thought and expression to all who live in America. "All are entitled to it; and none needs it more than the teacher." 147

of Thomas JefFerson 174 (P. L. Ford ed. I892-99): “. . the illimitable freedom of the human mind to explore and to expose every subject susceptible of contemplation," quoted from RicharD HofsTAdTER \& Waiter P. Metzger, The Development of Academic Freedom in the United States 239 n.73 (1955).

${ }_{1 \%}$ Aolai Stevenson, Speeches 82 (1952).

140 "Test oaths are notorious tools of tyranny. When used to shackle the mind they are, or at least should be, unspeakably odious to a free people." Mr. Justice Black, in Wieman v. Updegraff, 344 U.S. 183,193 (1952).

${ }^{147}$ Per Douglas, J., in Adler v. Board of Education, 342 U.S. 485,508 (195I).

"Professors need more than this absence of governmental sanctions, more than a guarantee that they will not be jailed for the expression of their thoughts. If they are to be encouraged to pursue the truth wherever it may lead ... they need protection from all more matcrial sanctions, especially dismissal ....

". . . More than in most other occupations, the dismissal of a professor jeopardizes or destroys his eligibility for another position in his occupation. The occupational work of the vast majority of people is largely independent of their thought and speech. The professor's work consists of his thought and speech. If he loses his position for what he writes or says, he will, as a rule, have to leave his profession, and may no longer be able effectively to question and challenge accepted doctrines or effectively to defend challenged doctrines. And if some professors lose their positions for what they write or say, the effect on many other professors will be such that their usefulness to their students and to society will be gravely reduced."

Machlup, On Some Misconceptions Concerning Academic Freedom, 4I A.A.U.P. BuLL. 753, 755-56 (1955). 